\title{
Commentary: A Blueprint for Change in the Northwest Territories?
}

September 1992 marks the 25th anniversary of moving the Government of the Northwest Territories (GNWT) from Ottawa to Yellowknife. In that time, the growth of the territorial governmental process has been phenomenal. In 1967, most GNWT employees travelled in one plane going to Yellowknife, and the government's budget was about $\$ 14$ million. Today, there are almost 6000 GNWT employees and the budget is over $\$ 1.1$ billion. Strength at Two Levels ${ }^{1}$ (the Beatty Report) is certainly one of the more interesting and contentious reports commissioned by the GNWT. On the one hand it advocates expanding the powers of local governments in the region - hence, strength at the territorial and local levels of government. At the same time, if implemented, recommendations of the report would undermine part of the GNWT's power base in Yellowknife. The question then is: Will the report become a blueprint for change, or will it be just another document for decentralization, unheeded by Yellowknife?

The Beatty Report is about the high cost of government in the Northwest Territories (NWT). Its origins are rooted in two problems. One is a northern dilemma. The North has a severe economic problem. Unemployment, particularly in small communities, is more than twice the national average, and average income per capita is almost half the national average. For years, government's response to low economic development in the North has been to establish a safety net modelled on social welfare programs originating in the South. The cost of services and programs is increasing rapidly, while increases to the GNWT's public revenue base are declining. Michael Ballantyne, former finance minister and chairman of the Financial Management Board (FMB), put it succinctly in his letter transmitting the Beatty Report to the present chairman of the FMB of the 12th Legislative Assembly (elected in October 1991): "The cost of providing basic government service to the people of the NWT far exceeds the NWT's revenue raising capacity" (p. 1).

A second problem is reflected in a northern paradox. The government's safety net was provided by Ottawa and later, as powers were devolved to the GNWT, by the bureaucracy in Yellowknife. Programs and services include, for example, education, health care, housing, social services and economic development. In spite of these expensive programs and services, many people resent the centralized, bureaucratic delivery mechanism. Many individuals feel it is an intrusion into their lives and that they do not have control of their own destinies. Moreover, many feel that the process has created a kind of dependency in the North, to the extent that people look to government as the solution to their economic problems. Therefore the GNWT's FMB, in January 1991, commissioned the study to determine if "government effectiveness could be increased and if costs could be contained without large declines in service to the public" (p. 1).

The project director was Garry H. Beatty, who had worked as deputy minister of Finance and secretary of the Treasury Board in Saskatchewan, president of the Crown Investments Corporation in that province, and president and CEO of Manitoba Hydro. Project members included five senior staff from the GNWT, one former GNWT assistant deputy minister, one person from the Baffin Divisional Board of Education, one from the Inuvialuit Regional Corporation, one Native chief, one person seconded from the federal Department of Western Economic Diversification and two outside consultants with extensive experience working in the public sector. Their group's task was to recommend to the FMB of the 12th Legislative Assembly how it could reduce "the rate of expenditure growth to match the revenues that will be available in the future" (p. 2).

The problem is that 56000 NWT residents are over-governed; a province-like territorial government has the highest cost per capita of any jurisdiction in Canada. A number of facts and figures point to examples of excessive government. In the 64 communities throughout the NWT the "GNWT operates 375 programs delivered through 17 departments of government" (p. 21). There are 1500 elected politicians and some 800 statutory and other GNWT-sponsored bodies. In the non-taxed base communities, about 320 special-purpose bodies cost approximately $\$ 66$ million a year. "At the regional level there are regional and tribal councils, health, wildlife and educational boards and aboriginal organizations" (p. 92). Housing costs and subsidies alone amount to about $\$ 130$ million a year, or approximately $12 \%$ of the territorial budget. Including all levels of government, there are over 9000 public employees, almost half of the total labour force in the NWT. All of this represents a vast network of government in the NWT, and the task for the project members was to determine how it might be simplified and made more efficient.

The project group suggested two types of changes for reorganizing the GNWT: decentralization of responsibilities and consolidation of structures and programs. Decentralization of responsibility was needed because "Community governments are under-used in the north" (p. 17). The idea was that a community infrastructure existed but it did not have the power to act on problems inherent to the community. For

\footnotetext{
Strength at Two Levels: Report of the Project to Review the Operations and Structure of Northem Governments. 1991. Yellowknife:
} GNWT Financial Management Board. 
example, local government powers included water, sewers, streets, lighting, airports, fire protection, town planning, garbage collection and recreation. It was suggested that by the year 2000 local responsibilities include day care, economic development, housing, drug and alcohol treatment, welfare, schools (including adult education) and crisis shelters (p. 42). With these powers, community governments could be in the "forefront" of solving community problems (p. 43).

The problem was moving more "program authority and resources" to community governments (p. 46). To do this, the GNWT over time should enter into transfer agreements with communities, including multiyear block funding to enable them to carry out their new responsibilities. Negotiations would be on a community-to-community basis, the extent of the transfers being up to communities. An implementation group would be established, reporting to Cabinet, to carry out the transfer agreements. Thus, within 10-15 years, communities might have full responsibility for housing, buildings and public works, social welfare, education and the production and marketing of country foods. Community governments could carry out the responsibilities more efficiently than could a centralized agency in Yellowknife.

Consolidating responsibilities of the territorial government was also an integral part of the project group's recommendations. Effective performance by departments and agencies was encumbered by layers of management. For example, in 1985 there were 14 deputy ministers and 15 assistant deputy ministers; in 1990 there were 18 deputy ministers and 27 assistant deputy ministers (p. 84). In addition, "There are now too many departments, which is a major barrier to integrating and transferring programs to communities. Departments are pursuing too many different and sometimes conflicting directions" (p. 61). The existing GNWT administration would be collapsed into eight functional departments, and a number of boards, agencies and third party organizations would be reorganized and decentralized, the rationale being to make service agencies more efficient and more effective.

The Beatty Report provided an impetus for change in the NWT. In February 1992, the GNWT tabled its general outline for "Reshaping Northern Government." It noted that any new government design in the territory would take into account the Beatty recommendations, as well as from members and committees of the Legislative Assembly, from aboriginal and special interest groups and from the general public. In June 1992, the GNWT made more specific proposals, recommending some consolidation and some decentralization of administrative organizations. In a statement to the Legislature on 16 June, the government leader outlined the game plan. For example, the departments of Government Services and Public Works would be merged, as would the departments of Culture and Communications and Education.

In the same statement, a decentralization program was also announced. It was designed in part to assist those centres affected by the "sluggish" economy and budget reductions. It included, for example, the following moves: airport and transportation programs to Fort Simpson, Norman Wells and Baker Lake; the head office and administration of Arctic College to Iqaluit and Fort Smith; parts of health care administration to Inuvik and Rankin Inlet; the Science Institute headquarters to one of its research facilities; and the Highways Transport Board and Public Utilities Board to Hay River. The above changes represent consolidation and decentralization of administration. Changes in decision-making responsibilities at the community level have not occurred. Therefore it may be premature to assess the full impact of the Beatty Report.

The Beatty Report is not the only design for change on the table in the North. Since November 1991, the NWT has moved a step closer to division, and the establishment of Nunavut is highly probable. The direct governing of their own lands by the Inuit would certainly necessitate restructuring northern government. In the western Northwest Territories the Commission for Constitutional development issued its report in April 1992, "Working Toward a Common Future." It posed the possibility of a new constitutional process for the new territory, emphasizing the necessity of beginning authority relationships with people and communities. Its design would certainly restructure the governmental process in the NWT.

Thus the dominant view circulating in the NWT seems to be that change is required in northern government. Twenty-five years of evolution have created a centralized, cumbersome and expensive territorial government centred in Yellowknife. Many individuals and groups outside Yellowknife want a greater say in the policy-making process. A number of ideas exist about how the present system should be changed. The Beatty Report is one of those ideas, but one upon which the GNWT is relying heavily. Pressures on members of the Legislative. Assembly may force the government to incorporate a number of views in its plans for restructuring. But the question remains, will the GNWT actually embark on a process of change, where communities or regions actually have greater decision-making powers? This may be difficult for a government that has built up a great deal of inertia over 25 years.

Mark O. Dickerson 